Asian J. Med. Biol. Res. 2020, 6 (2), 187-195; doi: 10.3329/ajmbr.v6i2.48049

\author{
Asian Journal of \\ Medical and Biological Research \\ ISSN 2411-4472 (Print) 2412-5571 (Online) \\ www.ebupress.com/journal/ajmbr
}

\title{
Article \\ Phytochemical screening and antioxidant, antibacterial efficacy of Gynura procumbens (Lour.) Merr
}

\author{
M Nasiruddin $^{1^{*}}$ and Shankar Narayan Sinha ${ }^{2}$ \\ ${ }^{1}$ Department of Botany, University of Rajshahi, Bangladesh \\ ${ }^{2}$ Department of Botany, University of Kalyani, WB, India
}

*Corresponding author: Dr. Md. Nasiruddin, Associate Professor, Department of Botany, University of Rajshahi, Bangladesh. Phone: +8801719417225; E-mail: mnuddin@ ru.ac.bd

Received: 03 April 2020/Accepted: 06 June 2020/ Published: 30 June 2020

\begin{abstract}
The emergent medicinal plant Gynura procumbens to the greatest extent familiar in Bangladesh, India, Thailand and Southeast Asia. The plant usually used as a traditional medicine for the treatment of various diseases along with diabetes mellitus. The present investigation was try to display screen qualitative and quantitative phytochemical compositions of ethanol extract of Gynura procumbens leaves as an instance soluble sugar, total amino acids, protein, chlorophyll, flavonoids, tannins, phenol as standard techniques and antioxidant activity as DPPH radical scavenging assay and compare the antibacterial activity by using agar well diffusion method. Qualitative evaluation exhibit present of most of the phytochemicals and quantitative evaluation revealed primary chemical constituents consisting of amino acids $(16.34 \mathrm{mg} / \mathrm{g})$, soluble sugar $(1.81 \mathrm{mg} / \mathrm{g})$, total chlorophyll $(0.52 \mathrm{mg} / \mathrm{g})$, chlorophyll-a $(0.34 \mathrm{mg} / \mathrm{g})$, chlorophyll-b $(0.145 \mathrm{mg} / \mathrm{g})$ and lowest amount of phytochemical turned into protein $(0.12 \mathrm{mg} / \mathrm{g})$. Secondary chemical constituents together with flavonoids (30.32 $\mathrm{mg} / \mathrm{g})$, phenols $(10.17 \mathrm{mg} / \mathrm{g})$ and tannin $(0.96 \mathrm{mg} / \mathrm{g})$. The observation also confirmed great antioxidant activity in a concentration dependent manner via the scavenging of 1, 1-diphenyl-1-picrylhydrazyl radical (DPPH). Result confirmed that, the studied sample has high antioxidant efficacy. The antibacterial interest confirmed as negative effects in all bacteria's tested. These results advise that Gynura extract is a good herbal supply of bioactive compounds.
\end{abstract}

Keywords: Gynura procumbens; phytochemicals; antioxidant; antibacterial

\begin{abstract}
1. Introduction
Gynura procumbens is an annual evergreen shrub with a fleshy stem and purple tint found in special parts of Asia and widely used as a traditional medicine in Thailand and Southeast Asia (Lemmens et al., 1995). Since time immemorial, medicinal plant lives were used to alleviate human suffering (Qureshi et al., 2016). Even today, just about $80 \%$ of the world's population, mainly in Asia, Africa and Latin America's emerging and growing countries rely upon medicinal plants for their primary fitness care (Shapouri and Rosen, 2007). Flavonoids, alkaloids, carotinoids, tannins, antioxidants and phenolic compounds are some of the bioactive substances that may be derived from plants. Even at small levels, antioxidants inhibit the oxidation technique and feature a wide range of physiological capabilities in the body (Farzaneh and Carvalho, 2015). Thus, the development and use of more effective natural antioxidants and therefore the antioxidant residences of Gynura procumbens is desired in the experiment. In phrases of inhibitory capacity, G. Procumbens have been tested with the reduction of 1, 1-diphenyl-2-picrylhydrazyl (DPPH) power. In the 21st century, serious bacterial infections that have become proof against antibiotics have emerged as a major global fitness problem (Thomson, 2004). Plants have supplied humanity with herbal remedies for many infectious sicknesses for a protracted time; still nowadays as healing cursing in growing countries they play a critical position in primary fitness care (Murthy, 1995). The main intentions of this observe is consequently the commentary of phytochemicals, antioxidants and antibacterial interest of ethanolic extract of Gynura procumbens.
\end{abstract}


2. Material and Methods

\subsection{Materials}

The plant materials used in this investigation were grown in the Botanical Garden, Kalyani University, WB, India. Fresh leaves were collected from these cultivated plants and research work was carried out at the Microbiology Laboratory, Department of Botany, Kalyani University.

\subsection{Methods}

\subsubsection{Qualitative phytochemical analysis}

According to the methods of Cromwell, 1955 qualitative test (spot test) was carried out.

\subsubsection{Soluble sugar estimation}

The soluble sugar was estimated by the method of Chow and Landhausser, 2004.

\subsubsection{Amino acid estimation}

Amino acids were measured by modified ninhydrin method (Moore and Stein, 1948).

\subsubsection{Protein estimation}

Total proteins were measured using Folin-phenol reagent methods (Lowry et al., 1951).

\subsubsection{Chlorophyll estimation}

The amount of chlorophyll present in the plant leaves were determined by the method adopted by Arnon, 1949.

\subsubsection{Flavonoids estimation}

Flavonoid content was determined by spectrophotometric method (Quettier et al., 2000).

\subsubsection{Tannins estimation}

Tannins content of Gynura procumbens was estimated by following the method as described by (Fagbemi et al., 2005).

\subsubsection{Phenol estimation}

Phenolic content in the plant extract was determined by Folin-ciocalteu reagent method with slight modifications (Adedapo et al., 2009).

\subsubsection{Antioxidant activity}

Antioxidant activity of the plant extract were measured by DPPH (1, 1-diphenyl-1-picrylhydrazyl) radical scavenging assay (Kirtikar and Basu, 2006).

\subsubsection{Antibacterial activity}

The antibiotic used in this study was the kanamycin (Edruc Limited, Bangladesh) as a positive control. In the present investigation following bacterial species were used to study to determine the antibacterial activity of the crude extract of the Gynura procumbens plant. All of the bacterial species were collected from the ICDDRB (International Centre for Diarrheal Disease Research, Bangladesh).

\begin{tabular}{|l|l|l|l|}
\hline Collection number & Gram positive strain & Collection number & Gram negative strain \\
\hline 1. BMLRU1002 & Staphylococcus aureus & 6. BMLRU1003 & Escherichia coli \\
\hline 2. BMLRU1004 & Bacillus cereus & 7. BMLRU1005 & Klebsiella pneumonia \\
\hline 3. BMLRU1006 & Streptococcus- $\beta$-haemolyticus & 8. BMLRU1007 & Pseudomonas aeruginosa \\
\hline 4. BMLRU1008 & Bacillus subtilis & 9. BMLRU1009 & Salmonella typhi \\
\hline 5. BMLRU1012 & Sarcina lutea & 10. BMLRU1011 & Shigella dysenteriae \\
\hline
\end{tabular}

\subsubsection{Antibacterial disc diffusion bioassay}

The disc diffusion assay (Kirby-Bauer Method) was used to screen antibacterial activity (Bayer et al., 1966). 
2.2.3.2. Determination of the Minimum Inhibitory Concentration (MIC)

The determination of the Minimum Inhibitory Concentration (MIC) by the particular concentration of ethanol extract of plant G. procumbens were carried out by the method as describe by National committee for Clinical Laboratory Standard (Baron, 2001).

\subsubsection{Determination of the Minimum Bactericidal Concentration (MBC)}

The Minimum Bactericidal Concentration of plant extracts on the clinical bacterial isolates was done according to the method highlighted in National Committee for Clinical Laboratory (Baron, 2001).

\section{Results and Discussion}

\subsection{Phytochemicals}

In this part of the study, ethanolic leaf extracts of Gynura procumbens was examined qualitatively for their alkaloid, flavonoid, glycoside, terpenoid, saponin, tannin, steroids, carbohydrate, and phenol content. The presence of secondary metabolites were denoted by " + " sign and absence of secondary metabolites were denoted by "-" sign. This study, '+' means present, "++" means fairly present, "+++" means hugely present and " - " means absent (Table 1).

The qualitative study reveals that among the screening phytochemicals most of the phytochemicals were highly or moderately present in leaves of Gynura procumbens (Table 1). Carbohydrate, saponin, tannins, flavonoids were highly present in leaf of the plant. Moderately present phytochemicals were proteins, alkaloids, phenols, glycosides and steroids.

The primary chemical constituents which includes soluble sugars, amino acids, proteins, chlorophyll-a, chlorophyll-b, and total chlorophyll content have been expected with the help of well-known procedure, observed consequences have shown inside the Figure 1. In case of soluble sugar we used glucose as a standard. Amount of amino acids had been calculated the use of a standard curve prepared with glycine. Protein content was calculated through preparing well-known curve with bovine serum albumin (BSA). From this research we found highest quantity of phytochemical which includes amino acids $(16.34 \mathrm{mg} / \mathrm{g})$ it become accompanied by way of soluble sugar $(1.81 \mathrm{mg} / \mathrm{g})$, total chlorophyll $(0.52 \mathrm{mg} / \mathrm{g})$, Chloropgyll-a $(0.34 \mathrm{mg} / \mathrm{g})$, chlorophyll-b $(0.145 \mathrm{mg} / \mathrm{g})$ and lowest amount of phytochemical was proteins $(0.12 \mathrm{mg} / \mathrm{g})$ (Figure 1). All parameters were predicted by using dry weight basis besides the chlorophyll. The secondary chemical constituents together with phenols, flavonoids and tannins content have been predicted with the assist of standard procedure, determined outcomes have shown within the Figure 2. In case of phenols we used gallic acid as a widespread. Amount of flavonoids have been calculated the usage of a trendy curve prepared with quercetin equivalent $(\mathrm{QE})$. Tannins content turned into calculated through preparing fashionable curve with Tannic acid. From this research we found highest quantity of secondary phytochemical which includes flavonoids $(30.32 \mathrm{mg} / \mathrm{g})$ it became accompanied by means of phenols $(10.17 \mathrm{mg} / \mathrm{g})$ and lowest quantity of secondary phytochemical changed into tannin $(0.96 \mathrm{mg} / \mathrm{g}$ ) (Figure 2). All parameters of secondary constituents have been anticipated by means of dry weight bases.

Phytochemical screening helps to expose the chemical nature of the components of plant extracts. It may also be used to search for bioactive agents that might be used in the preparation as well as synthesis of very beneficial drugs. In the existing work, the ethanol leaf extract of G. procumbens changed into considered evaluation of primary and secondary metabolites. One of the most common biological properties of alkaloids is their toxicity in opposition to cells of foreign organisms. These activities were widely studied for their capability use in the removal and reduction of human cancer cells lines. Alkaloids which can be one of the largest groups of phytochemicals in plants have remarkable impact on human and this has led to the improvement of effective pain killer medications (Kam and Liew, 2002). Saponins and glycoside also are very vital classes of secondary metabolites as a few are cardio active and used in treatment of heart conditions (Oloyde, 2005). In quantitative take a look at we determined maximum amount of phytochemical which includes amino acids $(16.34 \mathrm{mg} / \mathrm{g})$ it changed into followed with the aid of soluble sugar $(1.813 \mathrm{mg} / \mathrm{g})$, total chlorophyll $(0.52 \mathrm{mg} / \mathrm{g})$, Chloropgyll-a $(0.34 \mathrm{mg} / \mathrm{g})$, chlorophyll-b $(0.145 \mathrm{mg} / \mathrm{g})$ and lowest amount of phytochemical changed into proteins $(0.12$ $\mathrm{mg} / \mathrm{g}$ ). On the other hand (Kaewseenjan et al., 2015) phytochemical analysis revealed the contents of chlorophyll-a, b and carotenoids in ethanolic Gynura extracts were $365.20 \pm 0.049,132.40 \pm 0.029$ and $53.20 \pm 0.034 \mu \mathrm{g} / \mathrm{g}$ dry weight respectively. Moreover, the ethanol Gynura extract confirmed the presence of saponins and anthraquinone glycosides had been absent.

Additionally, it may be concluded from the existing findings that G. procumbens (Lour). Merr. plant extract could be of considerable infers to the development of latest lifestyles saving drugs. However, further research is needed to perceive the specific compounds to use as a drug as main in the medicine. 


\subsection{Antioxidant analysis}

The extract of Gynura procumbens tested against to DPPH stable radicals spectrophotometrically which reveals that the novel scavenging activity of ethanol extract of $G$. procumbens possessed first-rate antioxidant capability by using improved with the growing concentration of the extract. To look at the scavenging activity of leaf of $G$. procumbens five different concentrations $(10,20,40,80$ and $160(\mu \mathrm{g} / \mathrm{ml}))$ had been used and the $\%$ scavenging activity of leaf become gradually accelerated $7.42 \%, 9.60 \%, 19.21 \%, 50.65 \%, 61.57 \%$ (Figure 3) by using increasing the concentration and incase of ascorbic acid's $\%$ of the scavenging activity became $21.83 \%, 53.27 \%$, $93.19 \%, 95.19 \%$, and $95.19 \%\left(25,50,100,200,400\right.$ conc.) (Figure 4), whereas IC $_{50}$ value of Gynura leaf and ascorbic acid were respectively $112.89 \mu \mathrm{g} / \mathrm{ml}$ and $9.52 \mu \mathrm{g} / \mathrm{ml}$ (Figure 5).

To be an excellent supply of herbal antioxidants $75 \%$ ethanolic extract fraction of G. procumbens leaves have been observed to exhibit maximum antioxidant activity. On the idea of the outcomes of this examine it's far clean that $G$. procumbens leaves extract can used as a capability source of effortlessly accessible herbal antioxidants in addition to in pharmaceutical applications.

Free radical scavenging assay is one of the most widely used strategies and has turn out to be a recurring work in organising the antioxidant activity of herbal extracts and phytochemicals. Hydrogen donating capacity is an index of primary antioxidants. DPPH is known to summary labile hydrogen and the ability to scavenge the DPPH radical is associated with the inhibition of lipid in step with oxidation (Matsubara et al., 1991) which is one of the characteristics features of chronic diabetes. In the prevailing work DPPH take delivery of an electron donated via an antioxidant compound, the DPPH decolorized which can be quantitatively measured from the changes in absorbance.

\subsection{Antibacterial activity}

Antibacterial activity of ethanolic leaf extract of Gynura procumbens against ten human pathogenic bacteria is summarized in Table 2 . In this study, the antibacterial activity of the extracts at concentrations of $30 \mu 1 /$ disc was positive control such as Kanamycin at dose of $30 \mu \mathrm{l} / \mathrm{disc}$. The results indicated that the extract displayed a variable degree of antibacterial activity on different tested strains negative control (disc containing only solvent ethanol) exhibited no zone of inhibition all the bacteria. But positive control (disc containing Kanamycin antibiotics) exhibited zone of inhibition against almost all of the organisms tested. The range of zone of $G$. procumbens was $12.88-19.75 \mathrm{~mm}$. The zones were measure to the nearest milllimeter using a ruler and values $<8 \mathrm{~mm}$ were considered as not active against microorganisms (Zhu et al., 2005). Diameter of highest zone of inhibition was found $19.75 \mathrm{~mm}(1000 \mathrm{mg} / \mathrm{ml})$ against Psudomonas aeruginosa and the lowest zone was found $12.88 \mathrm{~mm}$ against Shigella dysenteriae. So, the results shows that, Gram negative bacteria Pseudomonas aeruginosa and Shigella dysenteriae were the most sensitive strains with the strongest inhibition zones of $G$. procumbens leaf extract.

\subsubsection{Minimum Inhibitory Concentration (MIC) and Minimum Bactericidal Concentration (MBC)}

Results of Minimum Inhibitory Concentration (MIC) and Minimum Bactericidal Concentration (MBC) in ethanol solvents are shown in Table 3.

The result showed that in ethanol, Bacillus subtilis, Salmonella typhi and Shigella dysenteriae had the highest MIC $(200 \mathrm{mg} / \mathrm{ml})$ value and the lowest value was $(75 \mathrm{mg} / \mathrm{ml})$ showed that, Staphylococcus- $\beta$-haemolyticus, Bacillus aereus and Pseudomonas aeruginosa. The range of MIC values was $75-200 \mathrm{mg} / \mathrm{ml}$ against test of the bacterial strains. The highest MBC value was $350 \mathrm{mg} / \mathrm{ml}$ for Bacillus subtilis, Salmonella typhi and Shigella dysenteriae. The lowest MBC value was $(150 \mathrm{mg} / \mathrm{ml})$ for Staphylococcus- $\beta$-haemolyticus, Bacillus cerus and Pseudomonas aeruginosa. The range of MBC value were $(150-350 \mathrm{mg} / \mathrm{ml})$ against ten test of the bacteria.

In the present work, the antibacterial activity of leaf extract of G. procumbens (Lour.) Merr. has been decided towards Gram positive and Gram negative bacteria. In evaluating antibacterial organic solvents had been used. Ethanol extracts is, more active against the gram positive bacteria. This is in settlement with previous reports that plant extracts are more active against the gram positive bacteria than in opposition to the gram negative bacteria (Rabe et al., 1997). It is likewise glaring that gram negative bacteria have been extra resistant than gram positive bacteria.

The presence of antibacterial substances within the higher plants is nicely mounted (Srinivasan et al., 2001). Plants have provided a supply of proposal for novel drug compounds as plants derived drug treatments have made tremendous contribution towards human health. Plants are critical supply of potentially useful structure for the improvement of recent completed in case if Unani and Aurvedic system of drugs or it may be the bottom for the improvement of a medicinal drug, a natural blueprint for the improvement of a drug (Parekh and Chanda, 2007). 
Microorganism is the hid enemies to the mankind. They are small however caused a completely profound harm in human body. To remedy the drawbacks of chemical disinfectants the agent that have the ability to kill the microbes or arrest the multiplication are called the antibacterial capsules of which a few are located or established and some are hidden in vital raw materials for drug production. They may constitute a precious natural asset of country and make contributions an excellent deal to its health care device.

It is anticipated that about one quarter or prescribe drugs incorporate plant extract or active ingredients received from or modelled of plant substances (Tripathi and Tripathi, 2003).

Hence there's a dire need to observe the antimicrobial properties of herbs, so one can be helpful in the helped in identifying the active principle accountable for such activities and inside the growing tablets for the therapeutic use in human beings.

In the present investigation, the crude extracts of G. procumbens has been decided antibacterial activities in opposition to the sensitivity of ten pathogenic bacteria five Gram positive bacteria and five Gram negative bacteria and as compared to that of antibacterial antibiotic kanamycin. The ethanol extracts of G. procumbens was more powerful against gram positive and gram negative bacteria. The range of zone of ethanol leaf extract of G. procumbens was (12.88-19.75 mm) and diameter of maximum zone of inhibition was observed $19.75 \mathrm{~mm}$ $(1000 \mathrm{mg} / \mathrm{ml})$ against Pseudomonas aeruginosa and lowest zone of inhibition was found $8.86 \mathrm{~mm}$ against Shigella dysinteriae. Negative control (disc containing only solvent ethanol) reveals no zone of inhibition towards the complete examined organisms. But positive control exhibits zone of inhibition against to almost all the examined organisms and the range of zone were. So, the end result suggests that gram positive bacteria Bacillus cereus and gram negative bacteria Pseudomonas aeruginosa have been maximum touchy strains with most powerful inhibition zones of leaf extract of G. procumbens. Showed the lowest MIC value (75) against Staphylococcus- $\beta$-haemolyticus, Bacillus cereus and Pseudomonas aerginosa wherein MBC value (150 mg/ml) was against Staphylococcus- $\beta$-haemolyticus, Bacillus cereus and Pseudomonas aeruginosa.

However, the results advise that $G$. procumbens incorporate active components which qualify them for medicinal use. Ethanol leaf extract of G. procumbens is more effective antibacterial activity because of their highest zone of inhibition. The presence of phyto compounds in the extract such as phenols, tannins, alkaloids, glycosides, terpenoids, saponins and flavonoids as important constituents may be answerable for the antibacterial activities.

So the present look at scientifically validates using plant in conventional medication and it contributes to the improvement of standardized parameters of herbal drugs.

Table 1. Phytochemical screening of leaf extract of Gynura procumbens.

\begin{tabular}{|l|l|l|}
\hline Sl. No. & Phytochemicals & Interference \\
\hline 1 & Alkaloids & + \\
\hline 2 & Tri-terpene & + \\
\hline 3 & Phenol & + \\
\hline 4 & Saponin & +++ \\
\hline 5 & Tannin & +++ \\
\hline 6 & Flavonoids & +++ \\
\hline 7 & Glycoside & + \\
\hline 8 & Steroids & + \\
\hline
\end{tabular}

‘+' present, '++' fairly present, '+++' hugely present and '-' absent 
Asian J. Med. Biol. Res. 2020, 6 (2)

Table 2. Antibacterial activity of ethanolic leaf extract of Gynura procumbens against ten human pathogenic bacteria.

\begin{tabular}{|c|c|c|c|c|c|c|c|}
\hline \multirow{2}{*}{\multicolumn{2}{|c|}{ Bacterial species }} & \multicolumn{6}{|c|}{ Zone of inhibition (mm) } \\
\hline & & \multirow{2}{*}{$\begin{array}{l}\mathbf{4 0 0} \\
\mathbf{m g} / \mathrm{ml} \\
0 \\
\end{array}$} & \multirow{2}{*}{$\begin{array}{l}\mathbf{6 0 0} \mathbf{~ m g} / \mathbf{m l} \\
9.50 \pm 0.19 \\
\end{array}$} & \multirow{2}{*}{$\begin{array}{l}800 \mathbf{~ m g} / \mathbf{m l} \\
14.30 \pm 0.41 \\
\end{array}$} & \multirow{2}{*}{$\begin{array}{l}\mathbf{1 0 0 0} \mathbf{~ m g} / \mathbf{m l} \\
16.75 \pm 0.53 \\
\end{array}$} & \multirow{2}{*}{\begin{tabular}{|l|}
$\begin{array}{l}\text { Positive } \\
\text { control }\end{array}$ \\
$17.30 \pm 0.43$ \\
\end{tabular}} & \multirow{2}{*}{\begin{tabular}{|l|}
$\begin{array}{l}\text { Negative } \\
\text { control }\end{array}$ \\
- \\
\end{tabular}} \\
\hline \multirow{5}{*}{$\begin{array}{l}\mathrm{G}^{+} \\
\text {(ve) }\end{array}$} & Bacillus subtilis & & & & & & \\
\hline & Sarcinalutea & 0 & $10.31 \pm 0.33$ & $13.85 \pm 0.23$ & $16.15 \pm 0.15$ & $20.25 \pm 0.21$ & - \\
\hline & streptococcus- $\beta$-haemolytica & 0 & $10.23 \pm 0.23$ & $11.52 \pm 0.31$ & $13.95 \pm 0.25$ & $16.88 \pm 0.51$ & - \\
\hline & Staphylococcus aureus & 0 & $9.68 \pm 0.28$ & $13.25 \pm 0.21$ & $15.25 \pm 0.30$ & $18.51 \pm 0.32$ & - \\
\hline & Bacillus cereus & 0 & $11.28 \pm 0.38$ & $14.51 \pm 0.28$ & $15.95 \pm 0.21$ & $19.12 \pm 0.18$ & - \\
\hline \multirow{5}{*}{$\begin{array}{l}\mathrm{G}^{-} \\
\text {(ve) }\end{array}$} & Klebsiellapneumoniae & 0 & $9.25 \pm 0.51$ & $11.58 \pm 0.21$ & $15.88 \pm 0.23$ & $18.88 \pm 0.23$ & - \\
\hline & Salmonelatyphi & 0 & $10.88 \pm 0.31$ & $12.55 \pm 0.22$ & $16.88 \pm 0.38$ & $20.21 \pm 0.43$ & - \\
\hline & Pseudomonas aeruginosa & 0 & $12.88 \pm 0.24$ & $16.25 \pm 0.18$ & $19.75 \pm 0.24$ & $24.21 \pm 0.71$ & - \\
\hline & Escherichia coli & 0 & $9.75 \pm 0.34$ & $11.25 \pm 0.29$ & $16.38 \pm 0.38$ & $20.25 \pm 0.68$ & - \\
\hline & Shigelladysenteriae & 0 & $8.86 \pm 0.79$ & $10.53 \pm 0.19$ & $14.50 \pm 0.17$ & $16.79 \pm 0.61$ & - \\
\hline
\end{tabular}

Data are represented as mean $\pm S D$ of triplicate experiments $(-)=$ No inhibition, $(+)=$ No. Zone

Table 3. Minimum Inhibitory Concentration (MIC) and Minimum Bactericidal Concentration (MBC) for the ethanol leaf extract of $G$. procumbens.

\begin{tabular}{|l|l|l|}
\hline Name of the bacteria & MIC $(\mathbf{m g} / \mathbf{m l})$ & MBC $(\mathbf{m g} / \mathbf{m l})$ \\
\hline Gram positive & & \\
\hline Bacillus subtilis & 200 & 350 \\
\hline Sarcina lutea & 150 & 250 \\
\hline Streptococcus- $\beta$-haemolyticus & 75 & 150 \\
\hline Staphylococcus aureus & 150 & 250 \\
\hline Bacillus cereus & 75 & 150 \\
\hline Gram negative & & \\
\hline Klebsiella pneumoniae & 150 & 250 \\
\hline Sallmonella typhi & 200 & 350 \\
\hline Pseudomonas aeruginosa & 75 & 150 \\
\hline Escherichia coli & 150 & 200 \\
\hline Shigella dysenteria & 200 & 350 \\
\hline
\end{tabular}

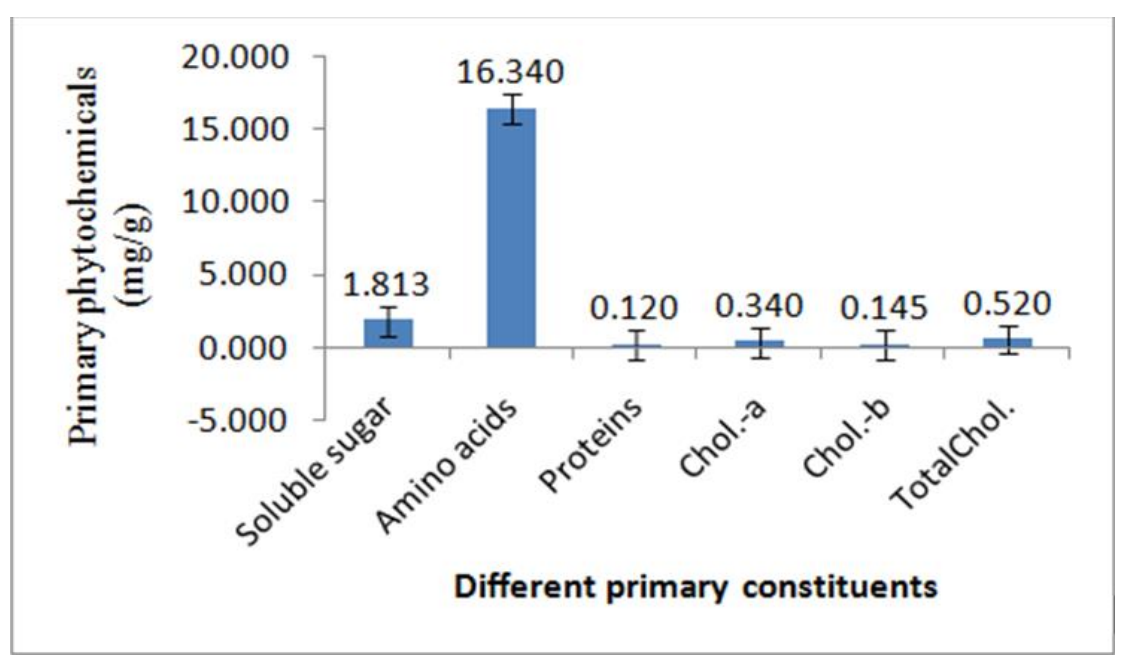

Figure 1. Primary constituents of leaf extract of Gynura procumbens. 


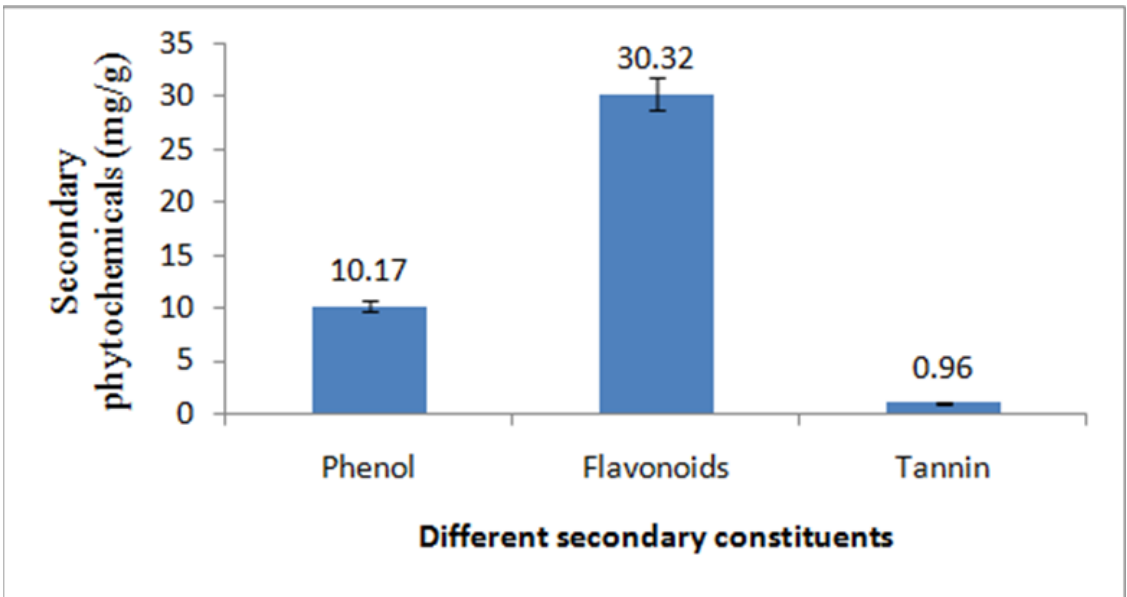

Figure 2. Secondary constituents of leaf extract of Gynura procumbens.

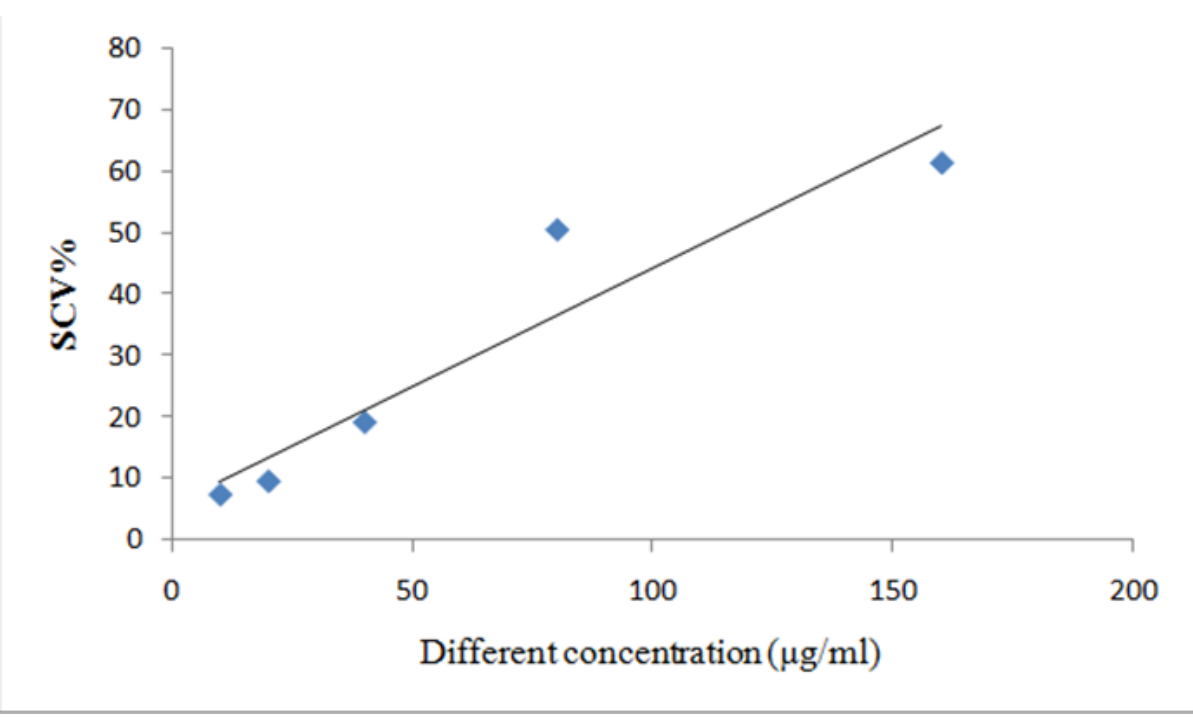

Figure 3. Scavenging activity percentage of Gynura procumbens leaf extract in different concentration.

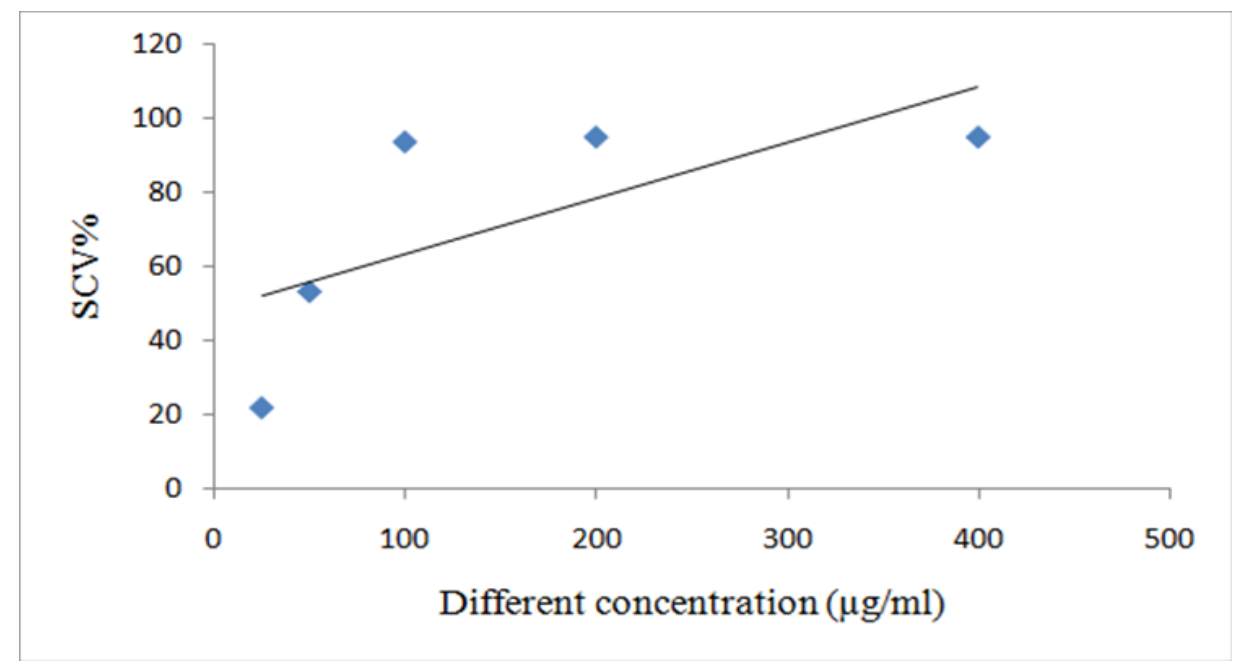

Figure 4. Scavenging activity percentage of vitamin- $\mathrm{C}$ in different concentration. 


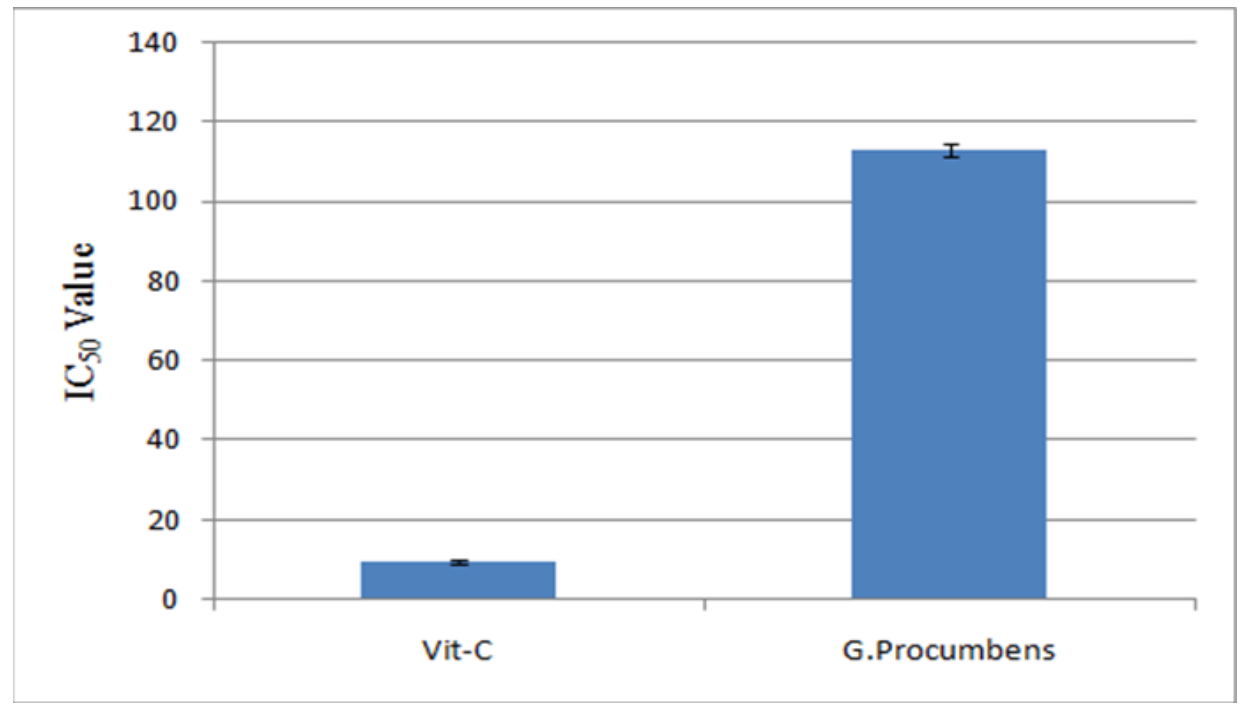

Figure 5. Comparative $\mathrm{IC}_{50}$ value of vitamin-C and Gynura procumbens.

\section{Conclusions}

On the basis of the prevailing investigation it is encouraged that the G. procumbens leaf bioactive components are applicable as antioxidative food dietary supplements and may use towards pathogenic microorganisms. This study can also generate and use scientific information in policy formulation and execution.

\section{Acknowledgements}

The authors specific their deepest feel of appreciation and heartfelt thanks to the Director, CSTDS, Channai, India for providing fellowship. The authors also thankful to Head of host institute of the Department of Botany, University of Kalyani, WB, India.

\section{Conflict of interest}

None to declare.

\section{References}

Adedapo AA, FO Jimoh, AJ Afolayan and PJ Masika, 2009. Antioxidant Properties of the Methanol Extracts of the Leaves and Stems of Celtis africana. Rec. Nat. Prod., 3: 23-31.

Arnon DI, 1949. Copper enzymes in isolated chloroplasts, polyphenoxidase in beta vulgaris. Plant Physiol., 24: $1-15$.

Baron EJ, 2001. Rapid identification of bacteria and yeast: summary of a National Committee for Clinical Laboratory Standards proposed guideline. Clin. Infect. Dis., 33: 220-225.

Bayer AW, WMM Kibry, JC Sherris and M Turck, 1966. Antibiotic susceptibility testing by a standardized single disc method. Am. J. Clin. Pathol., 45: 493-496.

Chow PS and SM Landhausser, 2004. A method for routine measurements of total sugar and starch content in woody plant tissues. Tree. physiol., 24: 1129-1136.

Cromwell BT, 1955. The alkaloids. In Modern Methods of Plant Analysis/Moderne Methoden der Pflanzenanalyse. Springer. Berlin. Heidelberg, pp. 367-516.

Fagbemi TN, AA Oshodi and KO Ipinmoroti, 2005. Processing effects on some antinutritional factors and in vitro multienzyme protein digestibility (IVPD) of three tropical seeds: breadnut (Artocarpus altilis), cashewnut (Anacardium occidentale) and fluted pumpkin (Telfairia occidentalis). Pak. J. Nutr., 4: 250-256.

Farzaneh V and IS Carvalho, 2015. A review of the health benefits potentials of herbal plant infusions and their mechanism of actions. Ind. Crops. Prod., 65: 247-258.

Kaewseejan N, V Sutthikhum and S Siriamornpun, 2015. Potential of Gynura procumbens leaves as source of flavonoid-enriched fractions with enhanced antioxidant capacity. J. Funct. Foods., 12: 120-128.

Kam PCA, and S Liew, 2002. Traditional Chinese herbal medicine and anesthesia. Anaesthesia, 57: 1083-1089. 
Kirtikar JR and Basu, 2006. Indian Medicinal plants. Allahabad. Lalit Mohan Pub., 3: 1841.

Lemmens RHMJ, I Soerianegara and WC Wong, 1995. Plant Resources of South-East Asia. Timber Trees: Minor Commercial Timbers, 5(2).

Lowry OH, NJ Rosebrough, AL Farr and RJ Randall, 1951. Protein measurement with the Folin phenol reagent. J. Biol. Chem., 193: 265-275.

Matsubara M, MT Girard, CL Kublin, C Cintron and ME Fini, 1991. Differential roles for two gelatinolytic enzymes of the matrix metalloproteinase family in the remodelling cornea. Dev. Biol., 147: 425-439.

Moore S and WH Stein, 1948. Photometric nin-hydrin method for use in the ehromatography of amino acids. J. Boil. Chem., 176: 367-388.

Murthy NA, 1995. Ayurvedic cure for common diseases. Orient Paperbacks.

Oloyede OI, 2005. Chemical profile of unripe pulp of Carica papaya. Pak. J. Nutr., 4: 379-381.

Parekh J and S Chanda, 2007. Antibacterial and phytochemical studies on twelve species of India medicinal plants. Afr. J. Bioethanol., 10: 175-181.

Quettier-Deleu C, B Gressier, J Vasseur, T Dine, C Brunet, M Luyckx, M Cazinc, JC Cazinc, F Bailleulb and F Trotin, 2000. Phenolic compounds and antioxidant activities of buckwheat (Fagopyrum esculentum Moench) hulls and flour. J. Ethnopharmacol., 72: 35-42.

Qureshi R, SA Ghazanfar, H Obied, V Vasileva and MA Tariq, 2016. Ethnobotany: a living science for alleviating human suffering. Evidence-Based Complementary and Alternative Medicine.

Rabe T and J Van Staden, 1997. Antibacterial activity of South African plants used for medicinal purposes. J. Ethnopharmacology, 56: 81-87.

Shapouri S and S Rosen, 2007. Global diet composition: factors behind the changes and implications and the new trends. Food Security Assessment, pp. 28-36.

Srinivasan D, S Nathan, T Suresh and O Perunalsamy, 2001. Antimicrobial activity of certain Indian medicinal plants used in folkloric medicine. J. Ethonpharmacol., 74: 217-220.

Thomson C J, E Power, H Ruebsamen-Waigmann and H Labischinski, 2004. Antibacterial research and development in the 21st Century-an industry perspective of the challenges. Curr. Opin. Microbiol, 7: 445450.

Tripathi L and JN Tripathi, 2003. Role of biotechnological medicinal plants.Trop. J. Pharma. Res., 2: 243-253.

Zhu Y, J Shi, W Shen, H Chen, X Dong and M Ruan, 2005. Preparation of novel hollow mesoporous silica spheres and their sustained-release property. Nanotechnology, 16: 2633. 